\title{
Reply to Andreas Boehle, Frank Kahmann, Thomas Oliver Henkel, Joerg Zimmermann and Stefan Machten's to the Letter to the editor Re: results of a randomized trial of treatment modalities in patients with low or early-intermediate risk prostate cancer (PREFERE trial)
}

\author{
Thomas Wiegel $^{1}$ - Peter Albers ${ }^{2}$ - Detlef Bartkowiak ${ }^{1} \cdot$ Roswitha Bussar-Maatz $^{3}$ - Martin Härter ${ }^{4}$. Glen Kristiansen ${ }^{5}$. \\ Peter Martus ${ }^{6}$. Stefan Wellek ${ }^{7}$. Heinz Schmidberger ${ }^{8} \cdot$ Klaus Grozinger $^{9} \cdot$ Peter Renner $^{10}$. Fried Schneider ${ }^{11}$. \\ Martin Burmester ${ }^{12} \cdot$ Michael Stöckle $^{13}$
}

(c) The Author(s) 2021

We thank the colleagues A. Boehle, F. Kahmann, T.O. Henkel, J. Zimmermann and S. Machtens for their remarks (Boehle et al. 2020).

First, we acknowledge the meticulous review of our paper and we revised the graphical errors in figure 3 referring to acute and 12-months toxicities of the treatment options. In addition, we have re-analyzed those toxicity data and provide a revised figure (Wiegel et al. 2020).

Second, the main message of our report is the unexpectedly high rate of termination of AS and the observation of a numerical higher toxicity rate of PSI versus EBRT. Details of patients with AS within PREFERE have been reported elsewhere (Albers et al. 2020). The higher number of toxicities and the results of the quality assurance of

This reply refers to the comment available online at https://doi. org/10.1007/s00432-020-03499-x.

Thomas Wiegel

thomas.wiegel@uniklinik-ulm.de

1 Department of Radiotherapy and Radiation Oncology, University Hospital Ulm, Albert-Einstein-Allee 23, 89081 Ulm, Germany

2 Department of Urology, University Hospital Düsseldorf, Düsseldorf, Germany

3 PREFERE Project Management, German Cancer Society, Berlin, Germany

4 Department of Medical Psychology, University Medical Center Hamburg-Eppendorf, Hamburg, Germany

5 Institute of Pathology, University Hospital Bonn, Bonn, Germany

6 Department of Clinical Epidemiology and Applied Biostatistics, University Hospital Tübingen, Tübingen, Germany the PSI-patients was indeed surprising and stimulated us to report on these observations in more detail (2020). Whether this observation will be indeed true on the long term will be a matter of a further analysis with longer follow-up.

Third, the PREFERE trial was the first randomized trial in prostate cancer which included PSI as a treatment option. We are grateful that most of the authors of the "Letter to the Editor" considerably contributed to this trial by enrolling patients or performing PSI (Stockinger et al. 2020). This gives us the opportunity to report on toxicities and efficacy of PSI within a prospectively controlled setting including details on quality assurance of every treatment option performed. Therefore, long-term data on oncological efficacy including PSI can be reported at the time of sufficient follow-up. As agreed with all contributors of PREFERE, oncological outcomes of all treatment options in patients

Department of Medical Biostatistics, Epidemiology and Informatics, University of Mainz, Mainz, Germany

8 Department of Radiotherapy and Radiation Oncology, University Hospital Mainz, Mainz, Germany

9 Department of Urology, Klinikum Leverkusen, Leverkusen, Germany

10 Center for Urology, Lübeck, Germany

11 Department of Urology, Klinikum Lippe Detmold, Detmold, Germany

12 Department of Urology, Vinzenzkrankenhaus, Hannover, Germany

13 Department of Urology, University Hospital Homburg/Saar, Homburg, Germany 
with localized prostate cancer may be reported only with at least 10 years follow-up and intentionally were not matter of debate of this report (Neal et al. 2020).

Finally, our report on preliminary data of a prematurely closed trial definitively did not intend to subjectively favor one over the other treatment option as suggested by Boehle et al. We unfortunately had to state that the optimal treatment of low and early intermediate PCa still remains unclear.

Funding Open Access funding enabled and organized by Projekt DEAL.

\section{Compliance with ethical standards}

\section{Conflict of interest None.}

Open Access This article is licensed under a Creative Commons Attribution 4.0 International License, which permits use, sharing, adaptation, distribution and reproduction in any medium or format, as long as you give appropriate credit to the original author(s) and the source, provide a link to the Creative Commons licence, and indicate if changes were made. The images or other third party material in this article are included in the article's Creative Commons licence, unless indicated otherwise in a credit line to the material. If material is not included in the article's Creative Commons licence and your intended use is not permitted by statutory regulation or exceeds the permitted use, you will need to obtain permission directly from the copyright holder. To view a copy of this licence, visit http://creativecommons.org/licenses/by/4.0/.

\section{References}

Albers P, Wiegel T, Schmidberger H, Bussar-Maatz R, Härter M, Kristiansen G, Martus P, Meisner C, Wellek S, Grozinger K,
Renner P, Burmester M, Schneider F, Stöckle M (2020) Termination rates and histological reclassification of active surveillance patients with low- and early intermediate-risk prostate cancer: results of the PREFERE trial. World J Urol. https://doi.org/10. 1007/s00345-020-03154-7

Boehle A, Kahmann F, Henkel TO, Zimmermann J, Machtens S (2021) Re: Results of a randomized trial of treatment modalities in patients with low or early-intermediate risk prostate cancer (PREFERE trial). J Cancer Res Clin Oncol. https://doi.org/10. 1007/s00432-020-03499-x

Neal DE, Metcalfe C, Donovan JL, Lane JA, Davis M, Young GJ, Dutton SJ, Walsh EI, Martin RM, Peters TJ, Turner EL, Mason M, Bryant R, Bollina P, Catto J, Doherty A, Gillatt D, Gnanapragasam V, Holding P, Hughes O, Kockelbergh R, Kynaston H, Oxley J, Paul A, Paez E, Rosario DJ, Rowe E, Staffurth J, Altman DG, Hamdy FC, ProtecT Study Group (2020) Ten-year mortality, disease progression, and treatment-related side effects in men with localised prostate cancer from the protect randomised controlled trial according to treatment received. Eur Urol 77(3):320-330. https://doi.org/10.1016/j.eururo.2019.10.030

Stockinger M, Karl H, Metz J, Maurer U, Machtens S, Wollschläger D, Martus P, Meisner C, Bussar-Maatz R, Albers P, Stöckle M, Wiegel T, Schmidberger H. Strahlenther Onkol (2020) PREFEREStudie zu Prostatakarzinomen mit niedrigem oder frühem intermediärem Risiko - Qualitätskontrolle der Permanenten SeedImplantation. (Suppl 1):196

Wiegel T, Albers P, Bartkowiak D, Bussar-Maatz R, Härter M, Kristiansen G, Martus P, Wellek S, Schmidberger H, Grozinger K, Renner P, Schneider F, Burmester M, Michael Stöckle J (2020) Results of a randomized trial of treatment modalities in patients with low or early-intermediate risk prostate cancer (PREFERE trial). Cancer Res Clin Oncol. https://doi.org/10.1007/s00432020-03327-2 (Online ahead of print. PMID: 32886212)

Publisher's Note Springer Nature remains neutral with regard to jurisdictional claims in published maps and institutional affiliations. 